Article

\title{
The Basis for Coexistence Found from within: The Mystic Universality and Ethicality of Donghak (東學, Eastern Learning)
}

\author{
Haeyoung Seong \\ College of Humanities, Seoul National University, Seoul 08826, Korea; lohela@snu.ac.kr
}

Received: 31 March 2020; Accepted: 21 May 2020; Published: 23 May 2020

\begin{abstract}
The rush of Western civilization, headed by Christianity, caused a considerable identity crisis in the 19th century Joseon dynasty. The founder of Donghak 東學, Suun Choe Je-u 水雲 崔濟愚， sought a way out of the crisis through religion. Suun contended that the religions of both east and west are grounded in the same Way of Heaven, and that it can be ascertained through an experience of mystical union induced by chanting a 21-character incantation. He also emphasized the importance of practicing this Way of Heaven in real life. According to him, the Western invasion is an act of selfishness, and goes against the Heavenly Way. The Heavenly Way is considered a foundation that enables communication and coexistence in a religiously diverse society. Despite the fact that his belief in the universality of the Heavenly Way is based on a personal experience-which is problematic to all mysticisms-Donghak provided a powerful discourse to deal with a variety of challenges of his time. In this age of religious pluralism, Suun's universalism is significant in exploring the intellectual and spiritual foundation of the modern pluralistic thoughts of Korea.
\end{abstract}

Keywords: Suun Choe Je-u; Joseon dynasty; Donghak; religious pluralism; mysticism; universalism; ethics; perennial philosophy

\section{Suun Choe Je-u 水雲 崔濟愚 and Donghak 東學 or Eastern Learning}

During the 19th century, the Joseon dynasty was going through a number of problems both domestic and foreign. ${ }^{1}$ From within, it was suffering from political chaos; from without, stronger nations such as Russia, China and Japan were out to exploit it. The introduction of Christianity and other western civilizations to what will later be called the hermit nation caused disruptions that shook the traditional world view to its very core. Suun Choe Je-u (1824-1864) is a figure that sought a way out of this chaos through religion. ${ }^{2}$ Based on his own unique religious experience, he founded Donghak, a new religion whose name means “Eastern Learnings" as opposed to the "Western Learnings 西學," which was the name for Christianity at the time.

Suun was executed in 1864 for his radical belief that all humans are equal. His successor, Haewol Choi Si-hyong (海月 崔時亨, 1827-1898), used the phrase 'Serve others as you would Hanullim (事人 如天)' to proselyte Donghak. The Donghak Peasant Revolution developed later into an uprising using force in the name of equality and resistance against foreign invasions. However, they were soon

\footnotetext{
Joseon is the name of the ruling dynasty in Korea from 1392 to 1910.

Suun Choe Je-u was born in 1824, into a ruined but aristocratic family. He wandered all across Joseon, practicing religious asceticism until he was thirty. In 1859, when he was thirty-five, he settled in his hometown Yongdam 龍潭 to continue asceticism, then had an encounter with the Sangje 上帝 in a religious experience the following year in 1860. After that, he founded Donghak 東學 and spread the teaching, but was arrested under the charge of "deluding the world and deceiving the people," and was executed in 1864 at the age of 40 (Pyo 2004).
} 
overcome by forces from the Joseon and Japanese governments, and Haewol was arrested and executed. The third religious leader, Uiam Son Byeong-hui (義菴 孫秉熙, 1861-1922), changed the name of their religion to Chondogyo (天道敎 Teaching of the Heavenly Way) in 1905, and strove for modernization of the organization and religious doctrines. In the spirit of Donghak's anti-invasion sentiments, Chondogyo played its part in Joseon's fight against Japan during colonial times. Chondogyo still has a strong presence in Korean religion.

This paper focuses on Suun's religious solution-Donghak - to the social problems of Joseon. The paper consists largely of two parts. The first deals with what kind of religious solutions Suun was seeking while being faced with such heterogeneous worldviews as Christianity, while the second part examines critically how those solutions also functioned as the basis for interreligious communication and co-existence of cultures in his philosophy. Most of the previous research on Suun and Donghak in Korea have focused on historical themes (Yim 2015, pp. 61-92). There is not much research done on this topic in the discipline of religious studies, and even less from a religiously pluralistic point of view.

Research on the religiosity of Donghak has, in general, taken two different paths. The first is an analysis on the relationship between Donghak and other preexisting Asian religions-namely, the effects Confucianism, Buddhism and Daoism had on Donghak. Since Confucianism was the most dominant religion of the time, research on the relationship between Confucianism and Donghak takes up the majority. ${ }^{3}$ The second is research that focuses on the relationship between Christianity and Donghak. Most of these works were conducted by Christian theologians and focused on the comparison of the concepts of gods. ${ }^{4}$

In other words, not much research has been done on Suun's religious universalism as a response to contemporary religious pluralism. ${ }^{5}$ This paper will focus on this point to show how, in an extremely chaotic era, Suun intertwined mystical universalism and ethicality to communicate with heterogeneous worldviews and sought common grounds on which all religions can co-exist in peace.

\section{The Age of Turbulence-And Seeking a Way Out through Religion}

Suun lived in an era when foreign countries with superlative military forces invaded his country. When western culture, with Christianity at the forefront, was introduced to Joseon, some people could no longer hold on to the familiar worldview they had taken for granted for literally thousands of years-a worldview that had China in the center of the world-and it was as if Joseon was shaken from its foundations. The following is Suun's description of the chaotic times, as quoted from the Donghak Scripture, the Donggyeong Daejeon 東經大全.

Recently, our country has been filled with evil things. The people live in a time without peace. This is an indication of the bad fortune of our nation. The Western powers are victorious whenever they fight, and they succeed and takeover wherever they attack. There seems to be nothing that they cannot achieve. I am worried that if China is destroyed, Joseon may be next. Where can we find a way for supporting the nation and comforting the people? ${ }^{6}$

Suun wished to find a way out of this crisis. According to him, the problem was one of 'identity' (Pyo 2004, pp. 54-63). He also believed that selfishness of both individuals and groups was the root

3 Major works include the following: Yim (2003); Cha (2003); Cho (1990); Park (2000); Kim (2002). According to research, the consensus is that Donghak was greatly influenced by Confucianism. However, there are varying opinions, such as the view that Donghak is a creative reinvention of Confucianism seeking social changes (Cho 1990).

4 Major literature are as follows: Kim (1974); Kim (2003a); Kwon (2004). Conclusions differ from views that claim Donghak's god was outright influenced by the Christian god (Kwon 2004), to the idea that Suun reached an understanding of god that is similar to the Christian god but only through his own, personal religious experience (Kim 1974).

5 Lee (1996) is the only research in this category. Lee defines Suun's religious belief as 'Universalism centering on the Heavenly Way'.

6 “是故 我國惡疾滿世 民無四時之安 是亦傷害之數也 西洋戰勝功取 無事不成而 天下盡滅 亦不無脣亡之歎 輔國安民 計將安 出," (Kim and Yoon 2007, p. 5). 
cause of the problem-Western invasion being an example of such selfishness. ${ }^{7}$ That is why religion, as a doctrine that strives for completion of one's inner self, appealed to him as a solution. Suun believed that the religious solution of realizing and practicing the Will of Heaven could resolve the problem.

Suun insisted that the Will of Heaven could be practiced by overcoming fear and selfishness. The following are his three solutions. First, all cultures of the world, both east and west, share the same Heavenly Way (Chondo 天道), the universal truth. Secondly, the Heavenly Way is open to all beings, so it can be found within each and every one because Hanullim, the Supreme Being, exists within all of us. ${ }^{8}$ Thirdly, we must actualize the universal Heavenly Way that we have attained through practice of ethical values, which is the most crucial.

\section{The Heavenly Way, the Core Concept of Suun's Religious Solution}

\subsection{The Universalism of Truth: All Cultures Share the Identical Heavenly Way}

Suun was a universalist-he asserted that oriental and occidental cultures all shared the same Heavenly Way, and that is the ground on which he understood other religions. It is in this context that Suun claimed Donghak, the religion he founded, was a synthesis of Confucianism, Buddhism and Daoism. ${ }^{9}$ According to Suun, the three main religions of East Asia, namely Confucianism, Buddhism and Daoism, all contain parts of the Heavenly Way. The same applies to Donghak, his own teaching. He argues even Christianity shares the identical Heavenly Way.

The Western religion (Christianity) is similar but different. It has the appearance of worshipping God, but has no substance. They both have the same destiny as religions and their Way (Truth) is identical, but their doctrines are different. ${ }^{10}$

The phrase "their Way is identical" signifies that Christianity also partakes in the Heavenly Way that transcends time and space whereas the description "their doctrines are different" means that the Heavenly Way, although identical at root, may manifest in different ways.

Suun's contention is similar to Aldous Huxley's concept of perennial philosophy. Per Huxley, there is an unchanging religious truth called perennial philosophy, and different religions are but particular manifestations of the same truth for different cultural contexts (Huxley 1945, pp. vii-viii). This point of view is widely shared by many religious universalists such as H. Blavatsky, Vivekananda, Radhakrishnan and Ken Wilber. ${ }^{11}$ These scholars agree that mysticism is the proof that religions of the east and west are identical at the roots. William James, who claimed mysticism is the core of religion, was also of a similar opinion (James 1994, p. 413). The four defining characteristics of the mystical state of consciousness as recounted by James well reflect the universalist point of view. ${ }^{12}$ He claims that mysticism transcends cultural contexts such as doctrines or organizations.

7 "However, in current times the people of the world have selfish minds, and do not follow the Principle of Heaven nor care for the Will of Heaven. Therefore, my mind is always anxious and fearful, and I don't know what will happen in the future". “又此挽近以來一世之人各自爲心 不順天理 不顧天命 心常悚然莫知所向矣," (Kim and Yoon 2007, p. 4).

8 Hanullim or Hanul is Korean for God. Suun has many names for the Supreme Being-Sangje 上帝 (Supreme Being), Choenju 天主 (Heavenly Lord, or God), guisin 鬼神 (ghosts) or Hanullim 产늘님. Choenju or Sangje appear mostly in the Donggyeong Daejeon, recorded in Chinese characters, and Hanullim is used in Yongdamyusa which is written in Korean, but other than that, there is no difference in the significance of these expressions. Ju(主) in Choenju or lim in Hanullim (pronounced nim when by itself) signify that the Sangje is a personified, sentient being who should be respected and revered.

9 "My Way is a unification of Confucianism, Buddhism and Daoism. The Heavenly Way itself is not originally Confucianism, Buddhism and Daoism, but Confucianism, Buddhism and Daoism are partial truths of the Heavenly Way-they are ethical codes of the past. The Three Bonds and Five Relationships of Confucianism; Cultivation of Nature and Enlightenment of the Mind of Buddhism; Nurturing of one's Energy and Nature of Daoism are all parts of my Way. My Way, founded on the deepest foundations of Confucianism, Buddhism and Daoism, has its principle in the Heavenly Way and its applications in Confucianism, Buddhism and Daoism—so be careful not to misunderstand this." (Park 1921).

10 “曰: 與洋道無異者乎? 日: 洋學如斯而有異, 如而無實, 然而運則一也, 道則同也, 理則非也,” (Kim and Yoon 2007, p. 9).

11 For perennial philosophy and its religious significance, see Ferrer (2002).

12 The four defining characteristics according to James are ineffability, noetic quality, passivity and transiency (James 1994, pp. 414-17). 
However, it is not that Suun considered all religions to be entirely identical. According to him, religions differ by methods of expression and the virtues they value most. For example, Confucianism stresses the practice of humaneness, righteousness, propriety and wisdom, while Christianity emphasizes the importance of praying. On the other hand, according to the doctrine of Donghak, the believer can become one with God that resides within themselves through the practice of incantation. Despite all this, says Suun, Confucianism, Buddhism, Daoism, Christianity and Donghak fundamentally all teach of the same Heavenly Way. In this aspect, Suun's universalism functions as a basis for both understanding and reconciling with other religions, highlighting the uniqueness of Donghak's teaching and religious practice.

However, his universalism inevitably leads to the following questions. First of all, how could he ever be certain whether all religions are manifestations of a single Heavenly Way? In other words, what is the rational basis for his universalism? Suun asserts that this is possible through the personal experience of 'my mind is your mind (Osimjeukyeoshim 吾心郎汝心)'一an individual's experience of learning the Heavenly Way. It is a mystical claim that a transcendental, Supreme Being may be known through personal experience.

\subsection{Personal Mysticism: Heavenly Way Can Be Discovered within Everyone}

Mysticism may be defined as "a religious tradition that believes a person may experience union with the ultimate being, deliberately pursues practice to change one's consciousness, and is of a religious thought that explains the integrating relationship between the ultimate being, the universe and humankind based on the knowledge gained through said experience" (Seong 2014, p. 169). In short, mysticism has three components-experience, practice and thought—of which, an experience of mystical union is the core concept. Practice is the method with which to achieve that experience, and the thought is the theoretical effort to articulate the relationship between the ultimate being and the phenomenal world based on the knowledge gained through that experience (Seong 2014, pp. 169-72).

Suun contended that we could all become one with the Supreme Being, Hanullim. His core teaching is based on the mystical declaration that humankind and the Supreme Being are fundamentally identical. ${ }^{13}$ Suun's religious experience, as illustrated in Donghak literature, is roughly threefold - the first encounter with Hanullim in 1860, then conversation with the Heavenly Master (Chonsamundap 天師問答) and finally, the experience of 'my mind is your mind' ${ }^{14}$ In 1860, Suun has an encounter with the Supreme Being that introduces itself as Sangje 上帝. However, this encounter leaves Suun flustered and fearful as he had never expected to meet a personified god. ${ }^{15} \mathrm{To}$ him, a personified god that explicitly expresses his own will appeared Christian. Suun, when asked to spread the Teaching in the world, demands immediately whether he should 'teach the Western (Christian) truth'. ${ }^{16}$.

Compared to Christianity, the appearance of a personified god that talks to him as a teacher and imparts incantations are relatively rare in eastern religions such as Buddhism or Confucianism. ${ }^{17}$ The interaction with the Supreme Being itself sets Suun's earlier religious experiences apart from traditional eastern religions. Nonetheless, the fear and doubt Suun had for Sangje during the first encounter developed into trust after going through an intimate conversation termed Chonsamundap.

13 The identity between a person and God is expressed as Innaechon 人乃天 (All humans are divine). For the concept of human being as appears in Donghak, see Kim (1978, pp. 31-32).

14 Kim Yonghwi also analyzes Suun's religious experience in context of mysticism, and discusses the process from the first encounter with the Sangje to the experience of 'my mind is your mind' (Kim 2007, pp. 64-65). He also contends that Suun's religious experience lasted for several months until he realized that 'my mind is your mind' (Kim 2003b, pp. 217-42).

15 “不意四月, 心寒身戰, 疾不得執症, 言不得難狀之際, 有何仙語忽入耳中, 驚起探問, 則曰 “勿懼勿恐, 世人謂我上帝, 汝不知上 帝耶?" 問其所然, 曰 余亦無功, 故生汝世間, 敎人此法, 勿疑勿疑." (Kim and Yoon 2007, pp. 4-5).

16 日, “然則西道以敎人乎?”(Kim and Yoon 2007, pp. 4-5).

17 Christian theologists including Gyeongjae Kim especially focus on the fact that an andromorphous god is Donghak's greatest peculiarity that sets it apart from other eastern religions. For comparison between Buddhism and Donghak, see Han (2009, pp. 251-68). 
It is a form of channeling, with Suun asking the questions and Hanullim answering them. Channeling is a very common religious experience-it is a phenomenon of communicating, in diverse ways, with a non-material being in an altered state of mind. ${ }^{18}$.

However, the Supreme Being, as described in Donghak, does not stop at having a conversation, distinctive from the self. The declaration that the mind of God is in fact the mind of a human transcends such duality. Suun's experience of mystical union, after he has gone through Chonsamundap and Hanullim's test, is illustrated as follows.

The Chonsamundap took place from fifth of April of year 1860 to the twentieth of September of the same year. Among the many questions and answers that took place during that period of time, there was one time when Hanullim tested the Great Divine Teacher (Suun). The Sangje asked, "... Thus, I will give you the position of Minister, even though you have no title now, to save the world." ... "As even the Sangje teaches with the wrongful Way, I will never listen to the Sangje's order or teaching again," he vowed to himself, and did not listen even when the Sangje gave lessons, fasted for eleven days and did not change his mind. The Sangje declared, "Your will is good to behold, and your integrity is commendable! Your study has already reached its peak, your practice is already at the highest level and your behavior is nearly perfected-now I will grant you perpetual harmony". (Lee 1970, pp. 14-15)

The gift of the perpetual harmony that Sangje gave unto Suun after passing the test was the experience of mystical union with the Supreme Being.

The moment the Great Divine Teacher heard this, a new energy circulated in his consciousness and new thoughts arose in his mind, and the words of the Sangje that were heard from out of the air was now resounded from within the Great Divine Teacher's mind-it became the teaching that had descended from above, and he wrote down a lengthy script. He asked himself then answered himself, recited the eternal then sung the eternal; the Heaven and Earth, Sun and Moon, the stars, grass and trees, animals and beasts, humans and things all answered to the song; millions and billions miles of space spread before the eyes; millions and billions of years spread before the eyes so there was no space far or close and no time past or coming, so millions and billions of innumerable hours and space drifted inside the single piece that was my mind. (Yoon 2000, pp. 36-39)

The above passage is an illustration of a typical mystical state of consciousness. Such consciousness of infinity and perpetuity is representative of the extraordinary insight that comes with this state. Additionally, the defining characteristics of this state is that there is no longer a differentiation between the self and other, or the relativity of time and space. ${ }^{19}$ Suun's religious experience began with the first encounter, continued throughout several months of chonsamundap, and ended with an experience of mystical union. This process can be characterized by its shift from dualistic to monistic experience.

The incantation in 21 characters is the basic religious practice that Suun suggests in order to achieve mystical union. It consists of the incantation which prays for the descent of the Spirit一至氣 今至 願爲大降 jigi geumji weonwi daegang一and the main incantation一侍天主造化定永世不忘萬事知 si cheonju johwa jeong yeongse bulmang mansaji. Suun interprets the incantation as follows.

They asked, "What is the meaning of the incantation which prays for the descent of the Spirit?" I answered: "the ultimate ( $j i$ 至) means the highest and extremely great. The [ultimate] vital force (ji-gi 至氣) is like the mysterious Spirit, and it is vast and full in the universe. It touches

18 For different sorts of channeling and its religious significance, see Brown (1997).

19 James (1994, pp. 423-60) describes monism as all barriers between the individual and the real disappearing, or being absorbed by the One. 
and governs all things. It looks like it has a form, but it is difficult to describe. It seems to have sound, yet it is difficult to understand. It is the one Ultimate Energy of the vast universe. Geum-ji 今至 means that now one joins the church (Donghak/Chondogyo) and understand the meaning of uniting with the vital force (of God), Weon-wi 願爲 means hoping and praying. Dae-gang 大降 means uniting with the Ultimate Energy. Si 侍 means having the Divine Spirit within and expressing the vital force in life. When people realize this, they will keep it in their hearts without change, $J u$ 主 refers to respecting, honoring and serving God like one's own parents. Johwa 造化 means natural becoming and transformation. Jeong 定 means oneness with the Divine Virtue and deciding to have the mind of God. Yoengse 永 世 refers to the long life of humankind. Bulmang 不忘 means thinking about God always without forgetting. Mansa means many things. $J i$ 知 means understanding God's way and achieving wisdom. Thus, if one would think about and never forget the bright Truth and Virtue of God and the incantation, one will unite with the Ultimate Energy (ji-gi 至氣) of God and attain the perfect sagehood." 20 .

Incantation which prays for descent of the Spirit is literally that; by the recitation of the incantation, one is praying that the Hanullim will descend upon him or her. Reciting the main incantation is a religious practice that creates the mystical union of the individual with Hanullim. It also contains the explanation on the relationship between Hanullimm and humankind. At the moment of mystical union, our minds transform into something limitless and perpetual, and we learn firsthand that our minds are identical to that of Hanullim. ${ }^{21}$.

It is interesting that Suun claims that this incantation appears "in the literature of the present and those of the past." ${ }^{\prime 2}$ This belief is in agreement with Suun's universalism-that the Heavenly Way is captured in different forms in different times and places. While talking of the incantation, he stresses that the essence of reciting the incantation lies in sincerity. There may be many methods to discovering the ultimate truth, but he is of the opinion that the mindset of the practitioner is key. When we “preserve the good mind, rectify the vital force (守心定氣)” “naturally (無爲而化)”, the Hanullim within us will manifest himself (Kim and Yoon 2007, p. 10). He stresses repeatedly that without sincerity, the recitation of the incantation will be utterly useless. ${ }^{23}$

The key is to preserve the good mind and to have sincerity. Suun insists that this emphasis on preserving the good mind is what differentiates his teaching from Confucianism and makes it unique. ${ }^{24}$ Then, what is the standard with which one can judge if the good mind is being preserved? It is the presence of selfishness. Suun criticizes that the doctrines of Christianity are hollow because Westerners might claim they have the Way of Heaven, but in truth, they treat other human beings with utter

20 “日降靈之文 何爲其然也日至者 極焉之爲至 氣者虛靈蒼蒼 無事不涉 無事不命 然而如形而難狀 如聞而難見 是亦渾元之一 氣也今至者於斯入道 知其氣接者也願爲者 請祝之意也大降者氣化之願也“侍者 内有神靈 外有氣化一世之人各知不移者 也主者稱其尊而與父母同事者也造化者 無爲而化也定者 合其德定其心也 永世者人之平生也不忘者存想之意也 萬事者 數之多也 知者 知其道而受其知也故明明其德 念念不忘則 至化至氣 至於至聖," (Kim and Yoon 2007, pp. 10-11).

21 Choi Donghwi also asserts that "To have God within you is the mystical state of the human body and mind becoming one with God" (Choi 1999, pp. 1-21).

22 “日文之意何也日 至爲天主之字故 以言之今文有古文有,” (Kim and Yoon 2007, p. 10).

23 However, in order to realize the Way and to establish Virtue, one must have the genuine sincerity and learn from the right person. Some people hear bad rumors and believe them, and some people hear the wrong kind of incantation and recite it. Isn't it a terribly wrong and sad thing? “雖然 道成德立 在誠在人 或聞流言而修之 或聞流而誦焉 豈不非哉 敢不憫然," (Kim and Yoon 2007, p. 19).

24 “仁義禮智 先聖之所敉 修心正氣惟我之更定 (Humaneness, righteousness, propriety, and wisdom are the virtues taught by the former sages. Keeping a good mind and having the right spiritual force are the virtues established only by me)," (Kim and Yoon 2007, p. 18). 
contempt—only as means of achieving selfish ends for the individual or otherwise. ${ }^{25}$ A good example would be how they invaded other nations.

By the same token, Suun argues that Confucianism also stresses the importance of virtues such as humaneness, righteousness, propriety and wisdom, but the problem is that they fail to put these truths into practice, all owing to selfishness. Suun claims that without getting rid of this selfishness, there is no way to achieve sincerity or to preserve the good mind. When they discard selfishness and pursue sincerity, the Sangje-the Supreme Being-will emerge naturally from within themselves and become one with them. When that happens, religious practices and teachings that may appear outwardly different, will be proved to be identical as a universal Way of Heaven. In the end, the process of religious practice and the key of the conclusion is that one must discard selfishness.

It is limiting that Suun's only criticism is selfishness. As previous research shows, Confucianism greatly influenced Donghak in that Suun's religious thought was built upon Confucian ideas and worldview. Donggyeong Daejeon, the central Donghak scripture, borrows heavily from Confucian concepts, and Suun does not have any discord with the details of Confucianism (Yim 2003). Rather, he focused on the fact that even though other religions of his time share the foundation on the universal Heavenly Way, they have yet failed as a motivation to make the world a better place. ${ }^{26}$ Suun's expression that they have 'outrun their fortune' is not a criticism of other religions' doctrines, but the fact that they are no longer equipped with the force to change reality. ${ }^{27}$ These are the reasons that Suun finds that it is important to change the realities of 'right now, right here'. He offers an inner-worldly mysticism that emphasizes the ethical relationship with others. He stresses that one should become more sensitive to the relationship.

\subsection{The Ethical Relationalism: We Must Practice the Heavenly Way within Our Relationships}

The mystical belief that humans can learn the universal Way of Heaven leads to the necessity that one must become more sensitive in relationships as a moral being. There are three different kinds of relationships that Suun finds are important-the relationship between a person and God, the relationship between a person and another person, and the relationship between a person and the world.

In Donghak, this relationship may come down to a single concept; to serve God (sichonju 侍天主). The verb si 侍 which means to serve, is ostensibly an action that presupposes a dualistic distinction between the person that serves and Hanullim that is served. However, Suun stresses that Hanullim, who is the object of this act of serving, in fact resides within the self, so the one who serves also becomes the one that is served. Suun insists that people's faith should not be in Suun himself, but Hanullim that resides in each one of them. ${ }^{28}$ Put differently, when Hanullim becomes manifest in ourselves, the self and the absolute become one. Therefore, the significance of "serving (侍)" is only completely realized in the dynamic moment when the distinction between man and God disappears.

It is the same within the relationship between person and person. Treating man as God (sain yeocheon 事人如天) is the Donghak virtue that regulates the relationship between people (Yoon 2014,

25 “日吾道無爲而化矣 守其心正其氣 率其性受其敎 化出於自然之中也 西人言無次第書無㿝白而頓無爲天主之端只祝 自爲身之謀 (I answered, “Our Way is the Natural Way. If each person preserves a good mind, rectifies the vital force, follows their original nature, and receives the Divine teaching, all will turn out well naturally. The Westerners have no order in their words and no logic in their writings. There is no genuine service for God but they only pray for selfish ideas.)," (Kim and Yoon 2007, p. 10).

26 Christianity, with its faith in equality of all humans, also a great force of social reform-it was persecuted by the Joseon government along with Donghak. However, Suun's opinion of Christianity was that it was the backdrop to Western invasion of other cultures. He also criticized the fact that the church was against some of Joseon traditions such as ancestral rituals (Cho 2003).

27 "Confucianism and Buddhism may have outrun their fortune of several thousand years," (Yoon 2009, p. 325).

28 Do not have faith in me. Are you acting out of faith in me? He resides in you; should you leave something close and take from afar? The only thing I hope for is that [you] would only have faith in Hanullim, that those of you who have not yet escaped from ignorance should discard books pour your efforts in ascetic practice- - that is also ethics (Yoon 2009, p. 358). 
p. 45). To treat, as in the case of to serve, is a verb that assumes there is a distinction between the one that treats or serves and the one that is treated or served. It signifies that since the self and the other are all in service of Hanullim, one should respect the other as Hanullim. However, if we are ontologically identical within Hanullim, then there is no duality in 'treat' either. The action of serving each other becomes an action between Hanullim within the self and Hanullim within the other-it becomes a paradoxical relationship within the single absolute being.

This paradox of relationship is expanded into the relationship between a person and the world around them. Ichon sikchon 以天食天, the doctrine suggested by the second leader Haewol, literally means 'Heaven devouring Heaven' (Yoon 2014, pp. 284-85). Because food is another life form outside the self, on expanding its meaning, it could stand for the relationship between the self and all of nature. The act of eating, at first glance, requires a dual distinction between the self and object. However, when seen from the point of view that all things come from an identical root, it may be understood as Heaven eating itself, as Heaven is all of being in its entirety. As the distinction between the subject and the object is rendered moot in 'serve' or 'treat' - the one serving is in fact the one being served, the one treating is the one being treated - the same would be true for the verb 'eat'.

Now, each individual action, when seen from this point of view, is movement of the infinite Hanullim confirming the eternity of the self and the whole within the infinite Hanullim. ${ }^{29}$ When I am forming a relationship with Hanullim, other people or things, I must treat (侍, 事, 食) them as Hanullim; that is when the actions within these dual relationships become an action within the infinite Hanullim. Suun stresses that monistic factors are present in all dualistic relationships-and that only by realizing this will it be possible to sincerely respect one another within a dualistic relationship. This ethical aspect of Donghak originates from its unique concept of god-that Hanullim embraces all beings within it, and simultaneously can become personified to form close relationships with beings within it, as it did with Suun. ${ }^{30}$

Furthermore, the fact that Hanullim did not remain a mere metaphysical principle, but revealed Himself to Suun as a personified being, also played a part in fortifying the ethical aspect of Donghak. From their first encounter, Hanullim regrets chaos in the human world, and expresses its wish that things were better. ${ }^{31}$ Suun takes this to formulate a strong code of ethics for social participation. In short, in Donghak, being ethical involves being socially active-and this code of conduct is the combination of the revelation Suun received from Hanullim and his mystical experience.

It is from this particular point of view that Suun criticizes Confucianism, Buddhism, Daoism and Christianity—can they actually ease the pain that the world suffers? Christianity claims that one should love one's neighbor as one loves God-so, it apparently has the Heavenly Way. However, it came as a shock to Suun that Christians do not actually practice this Heavenly Way. For Suun who believed that Hanullim, who had appeared before him, and the Christian god were one and the same, the fact that Westerners would build churches on the land they had brutally invaded seemed to be contradictory to the divine will..$^{32}$ Especially, the Christian belief that god only resided in heaven went against his own mystical experience. ${ }^{33}$.

29 "We search infinitely, and know infinitely, so within this infinite boundary of God, isn't this the infinite me?" (Yoon 2009, p. 520)

30 Suun's panentheistic divinity simultaneously maintains a dualistic relationship and a monistic identity with humankind. For Donghak's unique concept of god, see Seong (2009).

31 “余亦無功, 故生汝世間, 㜞人此法, 勿疑勿疑 (I have not been able to find anyone to teach the Truth. Thus, I am sending you to the world to teach the Truth. Therefore, do not ever doubt it.)," (Kim and Yoon 2007, p. 4).

32 “至於庚申 傳聞西洋之人 以爲天主之意 不取富貴 功取天下 立其堂 行其道故 吾亦有其然豈其然之疑 (In 1860 there were rumors that in order to serve God's will, the Westerners were not seeking wealth or glory, yet they attacked and conquered the world, and built their churches and spread their religion. I also wonder whether it was true and why they did that)," (Kim and Yoon 2007, p. 4).

33 "It is as if they believe that the Supreme Being above only resides in [the specific place of] Heaven. It is unnecessary even to discuss the principles of yin and yang-it is just all futile talk," (Yoon 2009, p. 477). 
In the end, Suun decided that practice was more important than the mere awareness of the Heavenly Way. The core concept is whether one respects all humans as beings that serve Hanullim-as Hanullim itself. Suun's teaching did go beyond mere words. Suun, after coming out of the period of religious asceticism, bowed down to his wife, freed two female slaves, adopted one as his daughter and another as his daughter-in-law-all unprecedented behavior at the time. His actions were proclamations of defiance against the contemporary social inequalities. His determination to put his beliefs into action was how his teachings expanded into a full-blown social movement-the Donghak Peasant Revolution of $1894 .{ }^{34}$.

\section{Suun's Religious Solution and Religious Pluralism}

After the introduction of Christianity, Joseon went through an era of religious pluralism. Some became entirely infatuated with Christianity and idolized all its aspects, while others perceive them to be hatred and violent oppression. Suun, based on his universalism that all religions are expressions of the Heavenly Way, avoided either extremes and took the middle path. ${ }^{35}$ It was his belief that no particular religion could monopolize the truth. It was not that eastern religions were simply inferior to Christianity, nor was it exclusively superior to it. Neither extreme laudation nor hatred was acceptable to Suun.

However, Suun's universalism leads to the following three questions. One, if the Heavenly Way is identically manifest in all the religions, then is he ignoring the individual characteristics of different religions? If it is Suun's belief that each and every religion is an expression of the identical truth of eternity, then it might be criticized that distinctive uniqueness of each religion may be overlooked. Two, by sticking to the belief that all religions are equal as manifestations of Heavenly Way, would not there be a risk of relativism of values? If all religions were reflections of a universal truth, it might not be possible to pass even the slightest judgement on any religion. Three, how can the universality of the Heavenly Way be confirmed by an individual experience such as mystical union? It is a question of whether a personal experience can be an epistemological proof for a claim of transcendental truth. Surely it is not that Suun formulated the questions in this way, but taking his philosophy into consideration, one might come up with the following answers.

First, Suun did claim that all religions come from a single Heavenly Way, but it does not mean that he disregarded any difference between the religions. He explained that religions are clearly distinguishable from one another by their characteristic methods of practice, emphasis on teachings and the degree of ethical practice. ${ }^{36}$ For example, while Confucianism stresses the importance of humaneness, righteousness, propriety and wisdom (Kim and Yoon 2007, p. 18), the Eastern Learning, on the other hand, places importance on 'preserving the good mind and rectifying the vital force' and 'serving God' (Kim and Yoon 2007, p. 10). This is because all religions are reflections of particular times and circumstances. In this context, he believed that Donghak is a more fitting teaching for his contemporaries in Joseon. By the same token, he also claimed that although there are incantations for every era, the incantations of Donghak will be more useful for the people of Joseon. In short, despite his universalism, he did not completely disregard the differences in religions.

34 After the death of Suun, the ideals of Donghak were inherited and put into practice in the real world by the Donghak Peasant Revolution. It began in January of 1894 and took place in two waves, ending in defeat for the peasant army in November of the same year. The leader of the revolution, Jeon Bong-jun, was arrested and executed the following year, in March. (Pyo 2014, pp. 429-35).

35 John Hick offers the concept of 'the Real' as basis for communication between religions. If different religions are diverse manifestations of the ultimate being, it is his belief that a reality-centered approach can form a basis for inter-religion communication and understanding (Hick 1983, p. 133).

36 Hick claims that religion as a manifestation of the ultimate being inevitably has its limits and other unique characteristics, so intercommunication between religions deepens the understanding of the ultimate being (Hick 1982, p. 117). Hick's understanding is similar to Suun's claim that religion is a unique expression of a universal Way of Heaven, in several aspects. 
Second, against the risk of Suun's universalism falling into an extreme form of relativism that believes 'everything is right', he offers a solid standard particularly of ethical practice. All individuals and groups are equal in the aspect that it may approach the Heavenly Way. However, there are differences in the execution of their moral ideals. For example, invading other nations by force against their will for selfish purposes are definitely behaviors that go against the practice of the Heavenly Way, which presupposes mutual respect and love. ${ }^{37}$ This standard should be applied to both individuals and groups. Donghak's anti-foreign influence, anti-feudalism stance has its foundation on the imperative that the Heavenly Way must be practiced on both personal and group levels. The practice of the Heavenly Way is the standard by which a religion may be judged to be good or bad. Especially, when selfishness is functioning as a motivation for certain behavior, it is difficult to respect others' intent. Suun's religious universalism forms an intimate pair with the moral code of conduct that builds the society upon the mutual respect of individuals and groups.

Thirdly, Suun did not provide a clear answer to the question of whether a personal experience can function as the epistemological foundation for universal truth. He declares that because all human beings have Hanullim within them, this may be learned through incantation practice (Kim and Yoon 2007, p. 10). In other words, the possibility of mystical insight is the basic prerequisite for Donghak. Furthermore, those who accepted Suun's teaching took this for granted-Suun, although he declared that the experience of 'my mind is your mind' was how he confirmed the truth of the universal Heavenly Way, but never went on to discuss it in detail.

However, this question is the most fundamental dilemma that all mystical traditions face and does not pertain only to Donghak. Mysticism claims that the existence of the ultimate being can be perceived through an extraordinary experience, the mystical union. The vehicle that makes one awaken to the ultimate being is personal experience. Surely, numerous methods are offered as ways of achieving the experience by mystical traditions, such as incantation, prayer or meditation. It is also the case with Donghak. An earnest practice of incantation, discarding all selfishness, leads to the experience of union with the inner Hanullim.

It is true that Suun's mystical claim cannot be proven. The contention that personal experience functions as a confirmation for a transcendental Heavenly Way belongs to the realm of faith. Within a religious faith system, which Donghak is, this may be convincing enough for the believers that accept this prerequisite. However, for those who do not, this will not have any influence. This fact becomes apparent during the course of Donghak's ideals manifesting itself in the real world. The government of Joseon and contemporary Confucians regarded Donghak as a Christian teaching, incompatible with Confucianism, and executed Suun. ${ }^{38}$ It is ironic that those who opposed Donghak thought that Donghak's Hanullim was identical to the Christian god.

\section{Conclusion: The Paradoxical Center That Can Be Found from Within}

Suun Choe Je-u strove to find a way out of the chaos, formed by the encounter of eastern and western cultures, through religion. After intense religious asceticism, Suun reached the conclusion that all cultures share an identical Heavenly Way-his universalism. He believed that anyone can tap into the universal truths from within the self, and that this religious experience is the bridge of coexistence and communication that makes it possible to overcome any gap. From a universalist point of view, the West is not just an object of marvel, or something to disparage as simple owners of tools but without soul. Hanullim had allowed the universal Heavenly Way to everyone, so the dual distinction between the superior 'center' of the world and the inferior 'edges' did not mean anything to Suun. According

37 Hick also asserts that the standard for 'grading' the values of religious traditions is how they transition from self-centeredness to reality-centeredness (Hick 1981, p. 451).

38 “今此東學之稱, 全襲西洋之術, 而特移易名目, 眩亂虫蚌耳 (This title 'Donghak' is just another name for the tricks they use in the West, to confuse the foolish)," Seungjeongwonilgi [承政院日記]," (National Institute of Korean History 2020), http://sjw.history.go.kr/. 
to him, any Eastern person speaking of Western culture as 'ignorant of humaneness or righteousness' or any Westerner speaking of Eastern culture as barbaric are both going against the Heavenly Way.

Nevertheless, Suun's universalism is far from extreme relativism that claims everything is right-it is because Suun emphasized the moral practice of the universal Heavenly Way in historical reality rather than a simple intellectual enlightenment of it. Suun's universalism does not lose its meaning because it stresses the importance of ethical practice. Hanullim that resides within every one of us is the foundation of the communication of Eastern and Western culture, and the emphasis on practice functions as a mutual foundation. Suun, by discovering the center of the universe within the self, strove to overcome the duality that were immensely popular at the time. Because Hanullim is within all of us, it is not possible for a certain individual or a culture to be at the exclusive center. On the contrary, any individual or group that practices Hanullim's will the best is closer to becoming the center of the universe. It is Suun's core teaching that we become the center when we respect God, another person, or the world around us 'right now, right here.'.

Even though the ideals of Donghak failed to realize itself in the real world, Suun's insight can still shine a light on the modern world. Donghak declared on mystical grounds that all human life is precious-and made an effort to actualize these principles in the world. We are living in an age when religious pluralism is more valued than ever before in human history. Suun's claim, although it is limited by the premise of a personal experience, is worthy of attention. What he had offered was a vivid example of religious pluralism seeking communication and coexistence, based on his experience of mythical union. ${ }^{39}$

Funding: This work was supported by the Ministry of Education of the Republic of Korea and the National Research Foundation of Korea (NRF-2017S1A5A2A03068753).

Conflicts of Interest: The author declares no conflict of interest.

\section{References}

Brown, Michael F. 1997. The Channeling Zone: American Spirituality in an Anxious Age. Cambridge: Harvard University Press.

Cha, Seonghwan. 2003. Sinyugyowa Cheondogyo: Donghak Gongdongcheui Sin Gaenyeom Byeonhyeongeul Jungsimeuro [Neo-Confucianism and Chondoism: With Focus on the Transformation of the Concept of Deity in the Donghak Community]. Hangungmunhwayeongu [The Korean Cultural Studies] 2: 7-32.

Cho, Hyein. 1990. Donghakgwa Jujahak: Yugyojeok Jonggyogaehyeogui Maengnak [Donghak and Zhuxixue: The Context of a Confucian Religious Reformation]. Sahoewa Yeoksa [Society and History] 17: 142-67.

Cho, Gwang. 2003. Sipgusegi Huban Seohakgwa Donghagui Sanghogwangyee Gwanhan Yeongu [A Study on the Relationship between Donghak and Western Learning at the end of 19th century]. Donghakakbo [The Korea Journal of Donghak Studies] 6: 51-83.

Choi, Donghwi. 1999. Suunui Jonggyosasang [Religious Thoughts of Suun]. Donghagyeongu [Donghak Studies] 4: $1-21$.

Ferrer, Jorge N. 2002. Revisioning Transpersonal Theory: A Participatory Vision of Human Spirituality. Albany: SUNY Press.

Han, Seongja. 2009. Donghagui Hanullimgwa Bulgyoui Muasasange Daehan Bigyoyeongu [A Comparative Study on Hanulnim of Donghak and No-Self of Buddhism]. Jonggyogyoyukag yeongu [Religious Education Studies] 29: $251-68$.

Hick, John. 1981. On Grading Religions. Religious Studies 17: 451-67. [CrossRef]

Hick, John. 1982. God Has Many Names. Philadelphia: The Westminster Press.

Hick, John. 1983. The Theology of Religious Pluralism. Theology 86: 335-40. [CrossRef]

39 Kim Gyeongjae declares that Donghak originates from Suun's experience of 'my mind is your mind' or the experience of 'serving God', and that these experiences are Donghak's central core (Kim 1999, pp. 22-43). Kim Yonghwi also contends that Donghak is not a mere amalgam of Confucianism, Buddhism, Daoism and Christianity, but a unique religion that was formed in the active process of reevaluating his own religious experience (Kim 2009, pp. 36-67). 
Huxley, Aldous. 1945. The Perennial Philosophy. New York: Harper \& Row.

James, William. 1994. The Varieties of Religious Experience. New York: Modern Libraries.

Kim, Gyeongjae. 1974. Choesuunui Sin Gaenyeom [Choe Suun's Concept of God]. Hanguksasang [Korean Thoughts] 12: 45-62.

Kim, Yong Choon. 1978. The Ch'ondogyo Concept of Man: An Essence of Korean Thought. Seoul: Pan Korea Book.

Kim, Gyeongjae. 1999. Suunui Sicheonju Cheheomgwa Donghagui Singwan [The Sichonju experience of Suun and the Concept of God in Donghak]. Donghagyeongu [Donghak Studies] 4: 22-43.

Kim, Yonghwi. 2002. Yugyowa Donghak: Jonggyo Cheheomeul Tonghae Dallajin Yugyowaui Chabyeolseong [Confucianism and Donghak: The Deviation from Confucianism through Religious Experience]. Dongyang Cheolhagyeongu [Journal of Eastern Philosophy] 29: 31-56.

Kim, Yonghae. 2003a. Geuriseudogyowa Cheondogyoui Singwan Bigyo [A Comparison Between the Theism of Christianity And Cheondogyo]. Donghakakbo [The Korea Journal of Donghak Studies] 6: 85-125.

Kim, Yonghwi. 2003b. Choejeuui Sicheonjue Natanan Cheongwan [The Concept of God as Appears in Choe Je-u's Sichonju]. Hanguksasangsahak [The Study of Korean History of Thought] 20: 217-42.

Kim, Yonghwi. 2007. Uri Hangmuneuroseoui Donghak [Donghak as Korean Studies]. Seoul: Chaeksesang.

Kim, Yonghwi. 2009. Donghagui Seongnipgwa Seonggyeokgyujeonge Daehan Ilgochal: Samgyowaui Gwangyewa Sinbicheheomeul Jungsimeuro [A Contemplation on the Foundation and Characterization of Donghak: Focusing on the Relationship with Confucianism, Buddhism, Daoism and Mysticism]. Donghagyeongu [Donghak Studies] 27: 35-67.

Yong Choon Kim, and Suk San Yoon, transs. 2007, Chondogyo Scripture: Donggyeong Daejeon [Great Scripture of Eastern Learning]. Lanham: University Press of America.

Kwon, Jingwan. 2004. Donghagui Singwangwa Seohagui Singwan: Minjungsinhakjeok Gwanjeomeseo [The Understanding of the Divinity by the Eastern Learning and the Western Learning (Thomistic Catholicism): From the Perspective of Minjung Theology]. Sinhaksasang [Theological Thought] 127: 35-68.

Lee, Donhwa. 1970. Chondogyochanggeonsa [The History of the Foundation of Chondogyo]. Seoul: Gyeonginmunhwasa.

Lee, Wonjae. 1996. Donghakgwa Geuriseudo: Donghagui Sincheheomeul Jungsimeuro [Donghak and Christ: Focusing on Donghak's Divine Experience]. Hangungmunhwasinhakoe [The Society for Korean Cultural Theology] 1: $234-70$.

National Institute of Korean History. 2020. Seungjeongwon Ilgi [The Daily Records of Royal Secretariat of Joseon Dynasty]. Available online: http://sjw.history.go.kr/ (accessed on 30 April 2020).

Park, Inho. 1921. Chondogyoseo [Scriptures of Chondogyo]. Seoul: Chondogyojungangchongbu [Chondogyo Central Headquarters].

Park, Gyeonghwan. 2000. Donghagui Singwan: Jujahakjeok Jonjaeronui Geukbogeul Jungsimeuro [The Concept of God in Donghak: Focusing on Overcoming the Zhuxixue Ontology]. Donghakakbo [The Korea Journal of Donghak Studies] 2: 171-91.

Pyo, Yeongsam. 2004. Donghak 1: Suunui Samgwa Saenggak [Donghak vol.1: Life and Thought of Suun]. Seoul: Tongnamu. Pyo, Yeongsam. 2014. Pyo Yeongsamui Donghak Iyagi [Pyo Yeongsam's Story of Donghak]. Seoul: Mosineun Saramdeul. Seong, Haeyoung. 2009. Suun Choe Je-u Jonggyo Cheheomui Bigyojonggyohakjeok Gochal: 'CheheomHaeseokteul'Ui Sanghogwangyereul Jungsimeuro [A Contemplation on Suun Choe Je-u's Religious Experience from a Religious Studies Point of View: Focusing on the Interrelationship between Experience and Interpretation]. Donghakakbo [Donghak Bulletin] 18: 271-306.

Seong, Haeyoung. 2014. Sinbijuuiran Mueosinga?: Gaenyeome Daehan Ohaewa Yuyongseongeul Jungsimeuro [What is Mysticism?: Focusing on the Misunderstanding and Usefulness of the Concept]. Inmunnonchong [Journal of Humanities] 71: 153-87.

Yim, Taehong. 2003. Donghagui Seongnipgwajeonge Michin Yuhagui Yeonghyang [Confucian Influence on the Formation of Donghak]. Sinjonggyoyeongu [Journal of the Korean Academy of New Religions] 9: 116-44.

Yim, Taehong. 2015. Donghak Yeongu Isipnyeonui Hoego (1995-2014): Singwan, Sinbicheheom, Geurigo Bigyoyeongu [Retrospection of My 20 Years Studies on Donghak (1995-2014): Views of God, Mystical Experience and Comparative Studies]. Hangukcheolhangnonjip [The Journal of Korean Philosophical History] 45: 61-92.

Yoon, Seoksan. 2000. Chogidonghagui Yeoksa [History of Early Donghak]. Seoul: Sinseowon. 
Yoon, Seoksan. 2009. Juhae Donghakgyeongjeon: Donggyeongdaejeon·Yongdamnyusa [The Annotated Scriptures of Donghak: Donggyeongdaejeon and Yongdamyusa]. Seoul: Donghaksa.

Yoon, Seoksan. 2014. Ilhaneun Hanullim: Haewol Choi Si-hyoungui Samgwa Sasang [Working Hanullim: The Life and Teachings of Haewol Choi Si-hyoung]. Seoul: Mosineun Saramdeul.

(c) (

(C) 2020 by the author. Licensee MDPI, Basel, Switzerland. This article is an open access article distributed under the terms and conditions of the Creative Commons Attribution (CC BY) license (http://creativecommons.org/licenses/by/4.0/). 